\title{
$\mathbb{Z}$ Iuke $\mathfrak{Z}$ aw $\mathfrak{J}$ ournal
}

\section{THE MALAISE OF THE ADMINISTRATIVE PROCESS}

\section{Kurt L. HansLowe*}

PRAGMATISM is America's contribution to philosophic thought. It characterizes our approach to problems-be they scientific, industrial, or governmental. Generally we go about solving these problems unhampered by the burdens of dogma. We are practical and realistic. In sports we see our football coaches try to circumvent the rules"avoidance" is the term coined by the tax counsellors, I understandcausing the rule-makers to scramble, often unsuccessfully, in an attempt to keep up. And if we want more hits in baseball, why we "liven up" the ball! ${ }^{1}$

In government, this approach has given us a structure which is the very antithesis of what the theorist would characterize as a political order. Order implies clearly fixed principles of operation and development. It implies fairly distinct hierarchies of authority. It implies some clearly defined values and goals and some degree of symmetry in the structure of government. Our public administration is hardly hampered by any such confining concepts. Nothing is more obvious than this lack of direction on the part of our administrators. Burdened by a morass of detail, a good deal of which is probably unnecessary busywork, they are ignorant of the precise nature of the public interest which they are charged to protect. ${ }^{2}$

We are problem solvers. The Army has one kind of task and

* A.B. 1947, Yale University; LL.B. I95I, Harvard University. Associate Professor of Industrial and Labor Relations and of Law, Cornell University. Member of the Michigan bar. This article is a slightly modified version of a paper delivered at the Administrative Law Round Table, Association of American Law Schools, in Chicago, Illinois, in December, 1961.

${ }^{1}$ I appreciate that this is a point controverted by baseball manufacturers!

'Compare a recent analysis of these failings in Miller, The Public Interest Un defined, 10 J. PUB. L. 184 (1961). 
consequently is set up in one way. The Post Office is another matter and can be organized and staffed quite differently. The courts are something else again, and if they do not perform well in labor cases, we simply fix up another kind of agency to deal with labor cases. We do the same with unfair trade cases except when there is a special problem with the marketing of corporate securities, and then we set up a separate agency for that kind of advertising.

Our pragmatism has spawned a sprawling governmental organism held together by about as much skeletal underpinning as an amoeba. We are fond of calling this off-spring, its growth, its operation and its convulsions "the administrative process." And the lawyers have a special concern with the legitimizing element in this process, namely, administrative law-that odd, wonderful hybrid of constitutional law, procedure, and public administration. But many people are concerned over the directions which both the administrative process and administrative law have taken. Or perhaps it is more accurate to say that it is lack of direction with which we are most concerned.

Let me add that I am fond of administrative law. It has performed more admirably than perhaps we had a right to expect in the face of the political practicalities with which it has had to contend during the last half-century. Administrative law has served as the conscience of our administrative process. It has continued to make a tenacious attempt to fix unto the process of public administration some minimal ordering principles of constitutional government. One need but remember Kent v. Dulles ${ }^{3}$ or Green v. McElroy to see the point.

Notwithstanding, it has been a losing battle. The pressures leading to the multi-directed accretions to the bureaucratic establishments have been too immediate and too continuing to allow for any kind of firm fix on some constellation of constitutional principles. Indeed, both the advocacy of change, as well as the resistance to it, have tended to lead to the same result. The advocates of change want something new. The resistance they encounter results in tinkering, in compromises, and in narrowly particular solutions. And our untheoretical and pragmatic way of doing things has prevented us from focusing on broad questions of governmental theory. Or, if we do occasionally focus on those questions, it is with the object of winning a law suit. This is probably unavoidable, given our constitutional structure and tradition. But it may not always be the best forum in which to conduct a constitutional debate.

\footnotetext{
${ }^{3} 357$ U.S. Ir6 (1958).

360 U.S. 474 (1959).
} 
It was not always true of our political practitioners that theory of government was irrelevant to the political process. Madison, Hamilton, Jefferson, Adams, Franklin, Morris and the rest, albeit highly realistic political practitioners, knew what political theory in the grand sense was about. More importantly, they were sharply conscious of what the practical consequence of implementing a particular political theory was likely to be. Their constitutional and political dialogue was a continual blending of philosophy and practice. ${ }^{5}$

Thus, in erecting our governmental structure, they showed a nice appreciation of the needs of centralism in the face of a splintered society. At the same time, they recognized both the fairness and efficacy of some division of governmental functions and powers. Concededly, this is all very elementary civics and, so one might suggest, happily forgotten with the invention of the Interstate Commerce Commission and the decline and fall of the Schechter case. ${ }^{\boldsymbol{B}}$ But my point here is quite modest. Our basic governmental structure is based on political theory and philosophy. If it represents problem solving, it was problem solving resting on a coherent framework of political principle-not just random playing with administrative and political blocs. I am suggesting that the framers of the Constitution, despite their political and philosophic differences, had firm notions of the kind of society they wanted. That being the case, they addressed themselves sharply to the problem of building a governmental apparatus appropriate to such a society. Their focus was, I think, on fairness, on efficiency, and most especially on liberty.

The same cannot always be said about our developing governmental apparatus during the recent decades. Much of the evolution of the administrative process has been characterized by the element of randomness. This has been the consequence of our unfocused pragmatic approach, the difference between pragmatism and opportunism in government and politics often being more apparent than real. This, in turn, has largely diverted our attention from the long-run aims of governmentfairness and efficiency. This leads to the somewhat paradoxical conclusion that opportunistic pragmatism, except in the short run, may not work very well, at least in government.

\footnotetext{
${ }^{3}$ Sec, e.g., Beveridge, The Life of John Marshald passim (1916); Bowers, JefFERSON aNd HAMilton passim (i225); Bowers, JefFerson in POWER passim (1936); OLIVER, Alexander Hamilton passim (1906). The list could, of course, be long continued.

${ }^{\circ}$ Schechter Poultry Corp. v. United States, 295 U.S. 495 (1935).
} 
Let me make these observations more concrete. The rise of the commission movement is in virtually each instance traceable to some particular problem of economic or social policy which existing instruments of government seem ill-equipped to handle. Since the problem always has some special characteristics, dictates of practical necessity seem to call for a special instrument of government peculiarly designed to deal with these characteristics. This mollifies the opponents of change and regulation, because isolation of the problem and isolation of the instrument for its solution present a situation which can, both in the short run and especially in the long run, be contained. The solutions are specialized, limited, and temporizing. Thus, we have seen created separate commissions to deal with discriminatory railroad rates, other unfair methods of competition, unfair labor practices, and so forth.

The proponents of regulation are at the outset, of course, pleased in each separate instance because they have a stick purposefully designed to fit the size and shape of the head of some particular whipping boy. But the story of the tiring policeman, even if he is a specialist, lacking regular re-infusions of the blood of political responsibility, is too familiar to repeat here. ${ }^{7}$ Suffice it to say that the proponents of regulation through the administrative process, operating on principles of immediate practicality, may have lost sight of some fundamental political truths. What the proponents of regulation, in their haste to solve the immediate problem, fail to do is to explore with imagination the possibility of accomplishing their aim within the existing framework of government. Perhaps the mistake is to assume that, because that framework has failed to solve the particular problem, it is in some way fundamentally defective. In any case, whatever the reason, the approach seems generally to be the creation of a new and typically independent agency, rather than the enhancement, either in size or, which would be more important, in authority, of an existing governmental organ.

What has happened, in effect, is a failure to maintain the original constitutional architecture by modifications appropriate both to the changing needs of increasingly national markets and politics, and to the principles on which that architecture rested. As citizens and con-

${ }^{7}$ It is well told in Bernstein, Regulating Business ay INDEPENDENT Commission (1955). One hopes that Professor Bernstein's more recent call for more cmpirical work will not result in inundation. Bernstein, The Regulatory Process: $A$ Framework for Analysis, 26 LAW \& ConTEMP. PROB. 329, 335 (1961). 
sumers our paramount interest is in fairness and efficiency. Yet the piecemeal solutions to specific problems have all too often proven violative of both interests. Had we remained true to the cause of fairness and efficiency, we would have changed our system of legislative apportionment and representation to allow for viable regional and effective metropolitan governmental units, capable of coping with the advance of technology, trade, transport, communication, and the mushrooming city. We would thereby have insured genuine protection of citizen and consumer interests, instead of drifting more and more, toward a system of producer-oriented instruments of government. We would also most likely have minimized the shift of power from the legislative to the executive branch. Finally, we would have avoided the repeated patchwork efforts to meet these problems-efforts which became easy captive to the producer groups they are designed to regulate. Failure thus to remain true to principle has enabled varying producer interests to exploit the failings of the original structure to contend with arising problems of technological and economical evolution. The developing corporate system, for instance, exploited the inappropriateness of the state as a licensing agency, as is clear in the whole history of competitive laxity in chartering. Who would doubt that we would have a more sensible, simpler, fairer, and more effective governmental structure had we early enacted a National Companies Act, strictly delimiting rights, powers, and duties of interstate corporations. Little regulation beyond the Sherman Act would have been necessary, if that.

Instead, we embarked on a course of producer-oriented but seldom citizen and consumer-oriented, tugging and pulling which is well illustrated in the labor relations field. When, in 1935, the question of administration of the Wagner Act arose, the choice was made in favor of a new and independent National Labor Relations Board rather than of the office of the Secretary of Labor. The subsequent history of that Board is revealing and illustrative. The Board, because in its early days it was a vigorous agency, encountered heavy resistance and counterattacks from the regulated groups. The focus was upon the issue of improperly mingled functions and consequent unfairness. Concern over the NLRB, as well as over some of the other federal agencies, eventually produced the Administrative Procedure Act ${ }^{8}$ and the TaftHartley Amendments separating the General Counsel from the

\footnotetext{
60 Stat. 237 (1946), 5 U.S.C. § $1001-1011$ (1958).
} 
Board. ${ }^{9}$ As a temporizing compromise, the accomplishments of the Administrative Procedure Act have been minimal. We know how difficult it is to tell where the act changed, and where it codified preexisting practice. ${ }^{10}$ The impact of the organizational Taft-Hartley Amendments was also at best unimpressive; at worst, it created confusion. ${ }^{11}$ The subsequent disillusionment with the National Labor Relations Board has been striking. When the Federal Labor Reform Law of $1959^{12}$ was under consideration, no one from any part of the political and economic spectrum seriously suggested that the new act be administered either by the NLRB or by some other independent regulatory agency. Rather, the law is enforced by the Secretary of Labor, the Department of Justice, and the courts. And lately even trade union lawyers are talking of turning unfair labor practices adjudications over to the courts!

This shows that the opponents of the regulatory process, like its proponents, are largely motivated by considerations of practical short-run advantage. Those who opposed the NLRB in its early days were not really concerned with effective and fair government. In the course of purporting to make regulation "fair," they rendered it ineffectual. The sad story told by the Landis Report ${ }^{13}$ shows how far this process of deterioration has gone. Whether it be the National Labor Relations Board, the Interstate Commerce Commission, the Federal Power Commission, the Federal Communications Commission, the Civil Aeronautics Board, or the Federal Trade Commission, the fact seems to be that, with but very few exceptions, none of them has been doing a more than barely adequate job and some considerably worse than that. The conclusion seems inescapable that the competing pressures toward

\footnotetext{
${ }^{9}$ Sec. 3 (d), 61 Stat. 139 (1947), 29 U.S.C. \& 153 (d) (1958).

${ }^{10}$ Compare, e.g., American President Line, Ltd. v. Federal Maritime Board, II2 F. Supp. 346 (D.D.C. 1953), with Kansas City Power \& Light Co. v. McKay, 225 F.2d 924 (D.C. Cir.), cert. denied, 350 U.S. 884 (r955).

${ }^{22}$ See Klaus, The Taft-Hartley Experiment in Separation of NLRB Functions, $x$ IND. \& LAB. REL. REV. 37I, 379 (1958). As a solution to the difficulties engendered by the present compromise, more complete separation of executive and judicial function was recently suggested by an Advisory Panel on Labor-Management Relations Law, Senate Committee on Labor and Public Welfare, Report on Organization and Procedure of the National Labor Relations Board, S. Doc. No. 8I, 86th Cong., 2d Sess. (1960).

${ }_{12}$ Labor-Management Reporting and Disclosure Act of 1959, 73 Stat. 519 (1959), 29 U.S.C. $\$ \S 40$ I-53I (Supp. I, 1959).

${ }^{13}$ Staff of Senate CoMm. ON the Judiciary, 86Th CONG., 2D SEss., Report ON Regulatory Agencies to the President-Elect (Comm. Print 1960).
} 
effective regulation, on the one hand, and toward fairness to the regulated, on the other, have produced a situation where we have achieved neither goal.

Our approach has not only bequeathed us a process of public administration seriously vulnerable to corrosion; it has also resulted in a governmental structure with no rhyme or reason. The multi-state and multi-agency manner by which we control and regulate the large corporation is ridiculous. So is the fragmented, helter-skelter way in which we enforce whatever is left of our policy against monopoly. The hopeless morass which we deign to call our transportation policy is notorious and appalling. ${ }^{14}$ If we have a policy with respect to power, electric or otherwise, I do not know what it is. I do not even know who is in charge. I suspect it may not even be the industries! There is some evidence that even so late an arrival as atomic energy is creating problems. If these problems become serious, it will be because we have been unwilling to do hard, honest, and realistic thinking about the regulatory problems which that industry is beginning to pose. The kind of problem posed by the recent Power Reactor Development Co. litigation $^{15}$ strikes me as the inevitable by-product of our not really knowing what sort of government-industry relationship we want. Nor do we know what sort of atomic energy industry we want eventually to develop. This is inevitably reflected in a compromising commission attitude. And this is an attitude which is encouraged by a commission structure combining the functions of public interest regulation, implying a stern task-master, with industrial promotion, implying rather the opposite.

We are thus confronted by a situation which is at least moderately paradoxical. Having, for the sake of efficiency, developed the administrative process over the last half century or more, we now find that process to be slow, uncoordinated, ineffective, and in some instances corrupt. Among the more prominent recent reactions to this condition is the Landis Report. ${ }^{16}$ It detailed the present difficulties well enough. And to some extent it focused upon their source. When it came to pre-

\footnotetext{
"See the excellent study by Fulda, Competition in the Regulated INDUSTRIEs -Transportation (196i); Special Study Group, Senate Committee on InterSTATE aNd Foreign COMMerce, 87TH CONG., ist SESS., Report ON National Transportation Policy (Comm. Print 196I); Chase, The Crisis in Transportation, 26 The Progressive No. 3, p. 27 (March 1962).

${ }^{15}$ Power Reactor Development Co. v. International Union of Elec. Workers, AFL-CrO, 367 U.S. 396 (1961).

${ }^{10}$ Report, op. cit. supra note 13.
} 
scribing remedies, the Landis Report spoke of the need for bigger and better commission chairmen and for greater executive influence to achieve development and coordination of policy. One does not, however, derive a sense of radical reform from a reading of the Landis Report, which was doubtless shaped by considerations of political feasibility. Even so, its over-all impact has been less than a howling success, if not barely minimal. Several of the administration's reorganization proposals have floundered or been accepted in part only. Progress at best may be characterized.as modest. While this may be better than nothing, it is hardly good enough.

The Landis position might be described as an intermediate one. It recognizes the problem, points to the need for more vigorous executive direction, and makes moderate suggestions to that end. It entails, however, a continued acceptance of our basic administrative structure as it is. Thus the notion continues to be widely held that the blending in the administrative agency of executive, regulatory, rule-making and adjudicatory functions and powers is necessary and desirable, and that such separation of functions (especially of prosecuting and judging) should be accomplished internally within the agencies and generally below the agency head level. ${ }^{17}$ The basis for

${ }^{13}$ See, e.g., Kintner, The Current Ordeal of the Administrative Process: In Reply to Mr. Hector, 69 YALE L.J. 965 (1960). See also, Professor Davis' position with respect to proposals to reorganize the Atomic Energy Commission. In opposing proposals which would split off from the Commission its regulatory function concerning safety from its promotional and developmental activities, and would turn the former over to a separate board with comprehensive regulatory authority, he has written:

"The proposed Board will have a brake but no accelerator and no steering wheel. The AEC will continue to have all three-a brake, an accelerator, and a steering wheel, but it will be discouraged from using its brake. Is a bus more likely to avoid accidents if it has not only the usual driver with the usual control but also an extra operator with only a brake? I think the man with the brake will tend to use it too much and at the wrong time, and that the divided responsibility will increase the probability of accidents. Accidents are avoided by using the accelerator and the steering wheel, not just by using the brake, and especially are accidents avoided by the coordinated use of all three. In the atomic program, some risks should be undertaken in order to learn how to avoid accidents. Some risks should be undertaken in order to learn how to save lives; how many lives have been saved by atomic contributions to medical science alone? Some risks should be undertaken to further the developing science for benefits as yet undiscovered. What cost in lives is too much for the development of an atomic-powered plane or missile or earth satellite? If misuse of a brake brings crucial programs to a halt, the human cost may be immeasurable.

...

"The regulatory powers should continue in the AEC, the present unitary command should 
this approach would appear to be the idea that implementation of public policy requires such centralization. It might be observed that some degree of "frustration and stalemate" is a price of ordered liberty and that the price of fairness is perhaps some degree of inefficiency. There is, I think, an important difference between the kind of inefficiency consciously paid for as the price of a free system of government, and the inefficiences unintentionally and unexpectedly caused by a method of administration supposedly efficient but actually chaotic. In the first instance we know what we are doing and can minimize the effect. In the second case we do not know what we are about, and produce the opposite of the intended result.

Beyond that, I question the basic premise that centralization of function does result in efficiency. To the extent that the administrator is concerned with questions of fairness, he will be distracted from vigorous discharge of his executive, coordinating, planning and promotional functions. To the extent that he focuses upon the latter, he will necessarily tend to discount fairness and risks. If he tires to focus upon all these tasks, he will probably wind up discharging none of them well.

Drastic reforms are implicit in the position taken by the Hoover Commission, ${ }^{18}$ and by Louis Hector in his famous memodandum to President Eisenhower. ${ }^{19}$ To some extent, both point the same way. They assert that the commission as presently constituted, involves an improper commingling of functions rendering the discharge of these functions impossible. But the emphasis of the two positions is quite different. The Hoover Commission recommends establishment of an administrative court-a suggestion which, in general terms, I support. But the Hoover Commission's principal concern is with judicialization

not be disturbed, and no new Board should be created." STAFF OF JOINT COMM. ON ATOMIC ENERGY, 87TH CONG., 1ST SEsS., Views AND COMMENTS ON IMProving the. AEC Regulatory Process 29, 32 (Joint Coinm. Print 1961).

This particular issue has engendered considerable discussion. See, e.g., BERMAN AND Hydeman, The Atomic Energy Commission and Regulating Nuclear Facilities (1961), and the exchange between Professors Cavers and Davis in 1 ro U. PA. L. REv. 330-92 (1962). On the separation issue in general, Professor Davis' position appears to be more complex, favoring somewhat greater separation than is required by sec. 5 (c) of the Administrative Procedure Act, but not as much as was recommended by the second Hoover Commission. 2 Davis, Administrative Law Treatise \$\$ 13.01-.1 I (1958).

${ }^{28}$ Commission on Organization of THE EXECUTIVE Branch OF THE GOVERNMENT (1953-1955), RePort to THE CoNgress ON LEgal Services aNd Procedure (1955).

${ }^{20}$ Hector, Problems of the CAB and the Independent Regulatory Commissions, 69 YALE L.J. 931 (1960). 
as an end in itself. There is less concern with vigorous and effective government and with how this can be achieved.

This, on the other hand, is the point of Mr. Hector's principal emphasis. He suggests that the fusion of functions has produced a paralysis which is fair neither to the regulated groups, who are interested in due process, nor to the public, which has a stake in the firm development, enforcement, and coordination of policy. Mr. Hector's position leads to a conclusion of startling simplicity: the classical separation of governmental powers, quite apart from representing orthodox constitutional dogma, and despite the occasional inefficiencies and stalemates it entails, makes much operational and functional sense. It produces about as good a balance between fair government and effective government as can be achieved.

What does this suggest about the desirable shape of our regulatory machinery? I can only sketch it out in desperate brevity. First, our economic policy ought to be drawn into a coherent whole. This is a legislative task. We should stop the process of ad hoc tinkering and think seriously and hard about what kind of an economy we do want. If we decide that we want a free and competitive market economy, we should draw our economic policy code so that its principal thrust will unequivocally be in that direction.

This is not to minimize the difficulties of this legislative task. It can surely not be accomplished overnight. But two steps at least ought to be taken by Congress. First, in considering any new regulatory legislation, Congress ought to resolve basic policy issues on such elemental factors as protection versus competition, instead of leaving these dangling in the form of vaguely and ambiguously worded delegations. Second, difficult though it is, the job of commencing a major legislative overhaul of our entire cluttered-up regulatory framework must be approached and commenced. Only thus can we make a genuine start on administrative reform, and only thus will Congress ever be able to resume its proper role as a major source of our public law.

Next, we should arrange our executive and administrative branch so that it can achieve a coordinated strategy for the enforcement of our law and policy. At the minimum, this means scrapping our splintered mode of anti-trust enforcement and of corporate regulation. It requires, also, more coordinated and centralized policy formulation in the public utility areas of transport, communications, and power. It may require the creation of a new cabinet post of the first rank. Such a 
cabinet member might be the Secretary for Industrial and Economic Affairs, and might chair a Coordinating Commission, the members of which would include heads of bureaus responsible for various parts of the overall economic code. The commission should have general rulemaking authority over its constituent parts, and the chairman's relations to the Secretaries of Labor, Commerce, and Treasury might be similar to those established by the Defense Department merger among the secretaries of that department.

Such focusing of executive power and responsibility would seem to be essential to render rational coordination possible in the formulation and vigorous execution of policy. It would not assure such a result. But in the event of failure, responsibility could be much more easily pinpointed than is true now, with administrative ineptitude hidden in the shrouds of independent quasi-judiciality, making it impossible to find the locus of responsibility anywhere. And such centralization of executive power is justifiable not only on grounds of efficiency but also on grounds of fairness and constitutionality, if it is accompanied by an appropriate splitting off of the judicial function.

Hence-it is no accident that this is third-we should consider the creation of an independent system of United States Administrative Courts whose decisions would be subject to review by a United States Court of Administrative Appeals. Thus, while functions of formulation and enforcement of policy would be properly separated from those of adjudication, the latter would be in the hands of a system of expert tribunals. $^{20}$ This would, I submit, result in increased rather than diminished administrative effectiveness. Executive tasks could be.discharged unhampered by the inhibitions of administrative officials who see themselves as quasi-judges. More imaginative experimentation with shortened procedures on the part of administrative officials would be a likely result. A more generous use of the rule-making power

\footnotetext{
${ }^{20}$ Suggestions to similar effect have been made not only by the Hoover Commission, op. cit. supra note 18 , and by Hector, supra note 19 , but they have also been advanced in Special Study Group, Senate Committee on Interstate and Foreign Commerce, 87th Cong., ist Sess., Report on National Transportation Polıcy (Comm. Print 196r) (suggesting establishment of a Transportation Circuit Court of Appeals); Berman \& Hydeman, The Atomic Energy Commission and Regulating Nuclear Facilities (1961) (urging separation of regulatory from executive and promotional functions of the AEC); KAUPEN \& TURNER, ANTITRUST Policy: AN ECONOMic and Legal ANalysis (1960) (proposing an Industrial Reorganization Commission and Economic Court to administer and apply antitrust policies); Schwartz, Administrative Justice and its Place in the Legal Order, 30 N.Y.U.L. REv. 1390 (1955).
} 
probably would be made. This would be a result devoutly to be hoped for in connection with many transportation policy problems and with the formulation of basic rate formulae in such areas as, for example, the regulation of natural gas prices. In these fields, as well as others, our administrative process is at present encumbered by interminable trialtype proceedings entirely unsuited for resolution of what are essentially quasi-legislative rather than quasi-judicial disputes. Yet all these gains in efficiency could be achieved without loss of fairness, if at the same time there were made available expert and independent judicial review. Nor would there be need to fear excessive executive control if Congress initially discharged its legislative duties with sufficient precision.

By now it will be clear that I am not inhibited by questions of political feasibility! A few concluding observations are in order. The kind of regulatory framework I have outlined involves, of course, the very opposite of the day-to-day pragmatic tinkering so characteristic of us. It requires, instead, a firm fix on constitutional principle, and clear thinking about the sort of society and economy we want. On the last point especially our voice has, I think, for some time been quite muffled. It is my own view that we should determine that it is the free, competitive market economy which is at the core of our economic policy. We should determine that achievement of this goal is in the public interest. And we should determine that, where competition is unworkable, public interest regulation should aim for an approximation of competitive results.

Much of our present drift and lack of clarity about the nature of the public interest is, I believe, attributable to an increasing uncertainty about these aims. This leads to a final point. It may well be that the triangular kind of governmental scheme I have sketched is appropriate only to a free society coupled with a free economy. It is perhaps no accident that the regulatory commission typically has arisen to contend with malfunctioning markets. But if we are giving up on the market, we should say so. And in that case the commission system may become the dominant form of governmental activity. It is, in that event, to be preferred over excessive executive dominance over all of society's activities. A somewhat decentralized corporate-syndicalist form of industrial organization is probably better than Stalinization!

Perhaps we shall move toward the system envisioned by Professor Davis of "miniature republics," consisting of commissions and their 
labor-industry advisory committees happily cooperating in the administration of the industrial system. ${ }^{21}$ In that event it might even be nice to add a fifth wheel to the headless fourth branch in the form of an Ombudsman, ${ }^{22}$ who, if at all possible, should of course, be a professor! The only question left would then be, sed quis custodiet ipsum professorem?23

- But if we do all this we should be quite clear in our minds that we shall have largely abandoned the libertarian governmental and economic system we have professed in the past. If we are collectivists, let us say so!

$2 x$ "The industry-committee system under the Fair Labor Standards Act may at some future time become a forerunner of miniature republics operating in economic or functional areas within frameworks laid down by the Constitution and by Congress." I Davis, Administrative Law Treatise $\$ 6.03$ (1958). Some implications of such an approach are explored in Hanslowe, Regulation by Visible Public and Invisible Private Gosernment, 40 TEXas L. REV. 88 (196I).

- "2 Experjmentation with this device has been urged by Davis, Ombudsmen in America: Officers to Criticiciue Administrative Action, 109 U. PA. L. REv. 1057 (1961); Gellhorn, Administrative Procedute Reform: Hardy Perennial, 48 A.B.A.J. 243 $(1962)$.

- I gratefully acknowledge my debt to Harry Caplan, Goldwin Smith Professor of the Classical Languages \& Literature, Cornell University, for assistance in adapting to the situation at hand Jnvenal's famous saw about problems of guarding the guardians. Juvenal, Satire VI, Line 347 . 